\title{
The Attachment to, and Invasion of HeLa Cells by Salmonella typhimurium: The Contribution of Mannose-sensitive and Mannose- resistant Haemagglutinating Activities
}

\author{
By G. W. JONES* AND LEIGH A. RICHARDSON \\ Department of Microbiology and Immunology, University of Michigan, Ann Arbor, \\ Michigan 48109, U.S.A.
}

(Received 8 December 1980; revised 18 February 1981)

The association of the haemagglutinating activities of Salmonella typhimurium cultures with bacterial adhesion to HeLa cells, and the internalization of the bacteria by HeLa cells, was studied. Adhesion was not inhibited by $\alpha$-methyl-D-mannoside (i.e. adhesion was mannoseresistant), and only four of the six strains tested produced type 1 fimbriae and the associated mannose-sensitive haemagglutinin (MSHA). The other two strains belonged to the non-fimbriate FIRN biogroup. Cultures of all six strains contained a mannose-resistant haemagglutinating (MRHA) activity when grown at $37^{\circ} \mathrm{C}$, but cultures of only one fimbriate and one non-fimbriate strain did so when grown at $18{ }^{\circ} \mathrm{C}$. From the comparison of cultures grown at $18^{\circ} \mathrm{C}$ and $37^{\circ} \mathrm{C}$, and of mutant strains with the phenotypes MRHAnegative/MSHA-positive, or MRHA-positive/MSHA-negative, it was concluded that the MRHA activity was responsible for the attachment of salmonellae to HeLa cells. Only bacterial adhesion that was resistant to mannose resulted in the internalization of the bacteria by the HeLa cells.

\section{INTRODUCTION}

Of the many investigations of invasive intracellular pathogens and their host cells [for example, salmonellae - Takeuchi (1967), Giannella et al. (1973), Kihlström \& Edebo (1976), Kihlström \& Latkovic (1978) and Carrol et al. (1979); shigellae - LeBrec et al. (1964), Takeuchi et al. (1965), Gemski \& Formal (1975), Hale \& Bonventre (1979) and Hale et al. (1979); mycobacteria - Hart et al. (1972); chlamydiae - Becker (1978), Byrne \& Moulder (1978), Brownridge \& Wyrick (1979) and Gregory et al. (1979); toxoplasma - Norrby \& Lycke (1967) and Jones \& Hirsch (1972)], few have been concerned with the role of the bacterium prior to and during the initial phase of internalization. Pertinent studies of these early events by Kihlström \& Edebo (1976) established that Salmonella typhimurium attached to HeLa cells prior to their internalization and that attachment was greatest when a rough mutant $S$. typhimurium was employed. More recently, it has been shown that smooth $S$. typhimurium also readily attach to HeLa cells. The process involved an initial phase of reversible attachment which was followed by the essential phase of irreversible attachment (Jones et al., 1981) prior to the internalization of the bacteria by the HeLa cells. Irreversible attachment possibly mediated by bacterial adhesins (Jones et al., 1981) may then have triggered the internalization of the bacteria in ways similar to those necessary for the internalization of particles by phagocytes (Stossel, 1975; Silverstein et al., 1977).

The most apparent adhesive activities of cultures of $S$. typhimurium are those due to the presence of type 1 fimbriae (Duguid \& Old, 1980), which facilitate the attachment of the bacteria to a variety of surfaces and cause haemagglutination. All forms of attachment mediated by these organelles are inhibited in the presence of D-mannose (Duguid \& Old, 1980). 
However, $S$. typhimurium strains of the nun-fimbriate FIRN biogroup (Duguid et al., 1975) also adhere to HeLa cells (Jones et al., 1981). The possibility existed, therefore, that the attachment of $S$. typhimurium to HeLa cells was the result of an adhesive activity perhaps common to all $S$. typhimurium and hence not that mediated by type 1 fimbriae. Haemagglutinating activities may reflect adhesive mechanisms essential for the survival of bacteria in natural habitats (Jones, 1977; Beachey, 1980). Accordingly, both the mannose-sensitive haemagglutinin (MSHA) of type 1 fimbriae and possible mannose-resistant haemagglutinins (MRHA) of $S$. typhimurium cultures were investigated, and their role in enabling the bacteria to attach to, and invade HeLa cells was studied.

\section{METHODS}

Bacterial strains and cultures. Six wild-type strains described previously (Jones et al., 1981) and one laboratory strain derived from LT2 were used (Table 1). Bacteria were grown routinely in Brain-Heart Infusion (BHI) broth (Difco) at $37^{\circ} \mathrm{C}$ (Jones et al., 1981). For some experiments, cultures were grown on BHI agar (Difco) at $37^{\circ} \mathrm{C}$ or in $\mathrm{BHI}$ broth at $18^{\circ} \mathrm{C}$. Incubation was for $16-24 \mathrm{~h}$.

Test for mannose-sensitive haemagglutination (MSHA). MSHA activity was used as an indicator of type 1 fimbriae production. The test used was a modified form of the tile test described by Duguid et al. (1966). In this test, haemagglutination is a function of both the bacterial numbers and the time for which the bacteria and erythrocytes are in contact and therefore standard curves can be constructed from plots of these two parameters. Suspensions containing various concentrations of the reference fimbriate strain TML together with the non-fimbriate strain S850 were prepared in saline $(0.85 \%, w / v, ~ N a C l)$ such that the final bacterial concentration was always $5 \times$ $10^{10} \mathrm{ml}^{-1}$. Portions $(25 \mu \mathrm{l})$ of these bacterial suspensions were then mixed on a mechanical shaker with 2 vol. of a $1.5 \%(\mathrm{v} / \mathrm{v})$ suspension of methyl glyoxal-treated horse erythrocytes (Hirata \& Brandriss, 1968) in saline, and the time required for perceptible haemagglutination to occur was recorded. A standard curve was then constructed. Test bacteria were suspended in saline at a concentration of $5 \times 10^{10} \mathrm{ml}^{-1}$ and their haemagglutinating activity was measured as a function of time. Relative MSHA activities were then obtained by extrapolation from the standard curve. Cultures with a relative MSHA activity of 1.0 (equivalent to an undiluted suspension of strain TML at a concentration of $5 \times 10^{10}$ bacteria $\mathrm{ml}^{-1}$ ) agglutinated the erythrocytes within $5 \mathrm{~s}$ whereas cultures with the lowest measurable activity (a relative MSHA activity of 0.01 and equivalent to a 1 in 100 dilution of suspension of strain TML) caused haemagglutination in $3 \mathrm{~min}$. The mannose sensitivities of the haemagglutinins were measured in tests to which $0.1 \%(\mathrm{w} / \mathrm{v})$ D-mannose (Pfanstiehl Laboratories, Waukegan, Ill., U.S.A.) was added.

Test for mannose-resistant haemagglutination (MRHA). MRHA activity was detected with a microhaemagglutination technique which did not detect mannose-sensitive haemagglutinins (Jones \& Rutter, 1974). Bacteria were suspended in saline at a concentration of $5 \times 10^{10} \mathrm{ml}^{-1}$. A series of twofold dilutions were prepared in saline and in saline containing $0.2 \%(\mathrm{w} / \mathrm{v}) \mathrm{D}$-mannose, and equal volumes of a $1 \%(\mathrm{v} / \mathrm{v})$ suspension of methyl glyoxal-treated sheep erythrocytes in saline were added. Tests were incubated in an ice-bath for $2 \mathrm{~h}$. The haemagglutination titre was recorded as the reciprocal of the highest dilution of bacterial culture to cause complete haemagglutination in the presence of D-mannose (Jones \& Rutter, 1974).

Interactions of $S$. typhimurium and HeLa cells. The ability of $S$. typhimurium to irreversibly attach to HeLa cells and to be internalized by HeLa cells was measured as described by Jones et al. (1981). Irreversible attachment or adhesion was expressed as an adhesion index, i.e. the mean number of irreversibly attached salmonellae per HeLa cell. Bacteria in Hanks' Balanced Salt solution $\left(1 \times 10^{9} \mathrm{ml}^{-1}\right)$ were incubated for $30 \mathrm{~min}$ at $37^{\circ} \mathrm{C}$ with HeLa cell monolayers. The monolayers were then washed and treated with fluorescent antibody. The bacteria attached to 20-50 HeLa cells on each of two monolayers were counted. The mannose sensitivity of adhesion was measured in tests to which $\alpha$-methyl-D-mannose or D-mannose (Pfansteihl Laboratories) were added to final concentrations up to $1 \%(\mathrm{w} / \mathrm{v})$. The invasion index represented the proportion of the irreversibly attached salmonellae that had entered the HeLa cells after $3 \mathrm{~h}$ incubation. All analyses and interpretations were as described by Jones et al. (1981).

Isolation of mutants constitutive for type 1 fimbriae and MSHA production. Bacteria treated with $N$-methyl- $N^{\prime}$-nitro- $N$-nitrosoguanidine (NTG, Sigma) as described (Jones \& Freter, 1976) were grown on BHI agar plates and then passed five times on the same medium to repress fimbriae production. The bacteria were then harvested in saline, mixed with a $3 \%(\mathrm{v} / \mathrm{v})$ suspension of methyl glyoxal-treated horse erythrocytes and the mixtures were agitated to allow fimbriate bacteria to attach to the erythrocytes. The washed erythrocytes were then cultured on BHI agar and individual colonies were examined for MSHA activity. MSHA-positive colonies were subcultured 12 times on dry BHI agar plates and retested. Isolates [TML(AU6) and TML(AN2); Table 1] with relative MSHA activities of 1.0 to 0.9 after growth on BHI agar for this number of passages were characterized as constitutive mutants not subject to the typical phase variation of fimbriae production (Ottow, 
Table 1. Relevant properties of the strains of Salmonella typhimurium studied

Strain

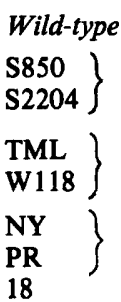

Mutants

TML(AU6) TML(AN2)

TML(Y42)

TML(N15)

TML(16)

TML(54)

TML(72)

TML(161A)
TML(N12)

Relevant properties

FIRN biogroup, MSHA-negative, MRHA-positive, attach to HeLa cells, invasive

Non-FIRN biotypes, MSHA-positive, MRHA-positive, attach to HeLa cells, invasive

Non-FIRN biotypes, MSHA-positive, MRHA-positive, attach to HeLa cells, invasive

MSHA-positive, derivative of strain LT2

Constitutive MSHA-positive forms of strain TML, otherwise as strain TML

MSHA-negative mutants of strain TML, otherwise as TML

MSHA-positive revertant of strain TML(N12), as strain TML

MRHA-negative mutants of strain TML, no attachment

to HeLa cells, not invasive, otherwise as strain TML

MRHA-positive revertant of strain TML(16), as strain TML

Transductants

S850(PR22T) MSHA-positive transductants of strain S850 produced with S850(PR 16T) P22 phage lysates of strain PR, otherwise as strain S850
Source/Reference(s)

Duguid et al. (1975), Jones

et al. (1981)

Giannella et al. (1973),

Jones et al. (1981),

Takeuchi (1967)

Obtained from E. J. Gangarosa,

Jones et al. (1981)

Obtained from E. Jackson

See text

See text

See text

See text

See text

See text

1975). Wild-type strains exhibited typical phase variation and failed to produce the MSHA after growth on agar for one to two passages.

Isolation of MSHA-negative mutants. Cultures mutagenized with NTG were grown in BHI broth to bring about maximal expression of the MSHA (see Results). Bacteria were collected by centrifugation, suspended in saline and then mixed with a $3 \%(\mathrm{v} / \mathrm{v})$ suspension of methyl glyoxal-treated horse erythrocytes to remove haemagglutinating bacteria. The bacteria not removed by the erythrocytes were recovered and grown in BHI broth. The process was repeated until the resulting cultures were only weakly haemagglutinating. Individual colonies were grown in broth and examined for MSHA activity. MSHA-negative isolates were designated TML(Y42) and TML(N12) (Table 1). An MSHA-positive revertant, designated TML(N15) (Table 1), was selected from passaged static broth cultures of strain TML(N12).

Isolation of MRHA-negative mutants. Bacteria were treated with u.v. light and grown in BHI broth to produce cultures of maximum MRHA content (see Results). The resulting cultures were repeatedly fractionated on phenyl-Sepharose (Pharmacia) columns (Smyth et al., 1978). On each occasion non-motile organisms were removed from the unadsorbed fraction by selecting for motility on semi-solid agar (Freter et al., 1979) before being grown in BHI broth and again subjected to chromatography. Single-colony isolates were examined for MRHA activity. MRHA-negative isolates were designated TML(16), TML(54) and TML(72) (Table 1), and a spontaneous MRHA-positive revertant isolated from a stored culture of strain TML(16) was designated TML(161A) (Table 1).

Isolation of MSHA-positive transductants of FIRN biotype strain S850. The technique was essentially similar to that described by Old \& Duguid (1971). Phage lysates prepared with bacteriophage $\mathrm{P}_{22} \mathrm{C}_{2} \mathrm{HT}$ (supplied by $\mathrm{Dr}$ Ethel Jackson of this department) and strains 18 or PR were used to infect cultures of strain S850. Infected cultures were grown in BHI broth for the selection of fimbriate forms (Old \& Duguid, 1971) and cultures that exhibited haemagglutinating activity with horse erythrocytes were plated on MacConkey agar base containing $1 \%$ (w/v) L-rhamnose (Sigma). Individual rhamnose-negative colonies of strain S850 were subcultured in broth and the relative MSHA activities were measured. MSHA-positive transductants used in the present study were designated S850(PR16T) and S850(PR22T) (Table 1).

Additional characterization of $S$. typhimurium strains. Cultures were tested for $\mathrm{O}$ and $\mathrm{H}$ antigens with specific antisera (Difco), for the loss of cell-wall components with rough- and smooth-specific phage (Wilkinson et al., 1972), for motility and for their ability to reversibly attach to HeLa cells (Jones et al., 1981). All cultures used in this study were motile (unless grown on agar), resistant to rough-specific phage, and if motile, able to reversibly attach to HeLa cells. The first and last properties were known to be important prerequisites for adhesion and internalization of the bacteria by the HeLa cells (Jones et al., 1981). Electron microscopic studies were conducted on preparations of bacteria made on parlodian-coated grids (Jones et al., 1981). 
Table 2. Haemagglutinating and adhesive properties of wild-type S. typhimurium strains

\begin{tabular}{|c|c|c|c|c|}
\hline \multirow[b]{2}{*}{ Strain } & \multirow{2}{*}{$\begin{array}{l}\text { Relative } \\
\text { MSHA } \\
\text { activity }\end{array}$} & \multirow[b]{2}{*}{$\begin{array}{c}\text { MRHA } \\
\text { titre }\end{array}$} & \multicolumn{2}{|c|}{$\begin{array}{l}\text { Adhesion index for HeLa } \\
\text { cells ( } \pm \text { s.D.) }\end{array}$} \\
\hline & & & $\begin{array}{l}\alpha-\mathbf{M M}^{*} \\
\text { absent }\end{array}$ & $\begin{array}{l}\alpha-\mathrm{MM}^{*} \\
\text { present }\end{array}$ \\
\hline S850 & 0.00 & 16 & $18 \cdot 4 \pm 3 \cdot 1$ & $18 \cdot 2 \pm 4 \cdot 1$ \\
\hline S2204 & 0.00 & 4 & $5 \cdot 8 \pm 2 \cdot 0$ & $5.6 \pm 1.8$ \\
\hline TML & 1.00 & 16 & $10 \cdot 4 \pm 2.3$ & $12 \cdot 6 \pm 2 \cdot 3$ \\
\hline W118 & 0.95 & 16 & $15 \cdot 2 \pm 4 \cdot 1$ & $16 \cdot 1 \pm 3 \cdot 8$ \\
\hline NY & 1.00 & 16 & $19 \cdot 6 \pm 2 \cdot 8$ & $21.4 \pm 2.9$ \\
\hline PR & 1.00 & 8 & $11 \cdot 1 \pm 3 \cdot 1$ & $11.9 \pm 2.7$ \\
\hline
\end{tabular}

\section{RESULTS}

\section{Haemagglutinating and adhesive properties of S. typhimurium strains}

Wild-type strains. MSHA activity was detected with the tile test in cultures of four of the six wild-type strains of $S$. typhimurium tested (Table 2). The haemagglutinins were most active on guinea-pig, horse and chicken erythrocytes and active to a lesser extent on sheep, cow and human erythrocytes. Treatment of the erythrocytes with methyl glyoxal had no noticeable effect on the haemagglutination reaction. The haemagglutinin content of cultures grown at $37^{\circ} \mathrm{C}$ reached near maximum levels after 16-24 h growth. Little or no MSHA activity was detected in cultures grown on BHI agar and no MRHA activity was detected. On the basis of these observations the MSHA activity was ascribed to the production of type 1 fimbriae (reviewed by Duguid \& Old, 1980). The existence in haemagglutinating cultures of fimbriae similar in size to type 1 fimbriae (Duguid et al., 1966) was confirmed by electron microscopy. Neither MSHA activity nor structures resembling type 1 fimbriae were detected in cultures of strains $\mathrm{S} 850$ and S2204.

MRHA activity was detected in broth- and agar-grown cultures of all six strains with the microhaemagglutination test (Table 2). The MRHA activity was similar with untreated and methyl glyoxal-treated erythrocytes of chicken, goose, guinca-pig, horse, cow, human and sheep and was greatest when tests were incubated in an ice-bath. Maximum MRHA titres of 8-32 were obtained with methyl glyoxal-treated sheep erythrocytes and 16-24 h old BHI broth cultures. The lowest dilution of bacterial suspension examined was a dilution of 1 in 2 with a bacterium to erythrocyte ratio of about 500 to 1 . The absence of MRHA in a culture was therefore recorded as $<2$.

Wild-type MSHA-positive strains of $S$. typhimurium were no more adhesive than the wild-type MSHA-negative strain S850, and in no instance was the adhesion index of an MSHA-positive strain reduced by the presence of D-mannose or $\alpha$-methyl-D-mannoside ( $1 \%$, $w / v$, or less) (Table 2). On the contrary, the presence of these carbohydrates occasionally elevated adhesion above that of bacteria tested in Hanks' solution. D-Mannose and $\alpha$-methyl-D-mannoside had no effect on the adhesion of non-fimbriate bacteria to HeLa cells (Table 2).

Mutants constitutive for MSHA production. Broth-grown cultures of the parental strain TML and the two constitutive mutant strains TML(AU6) and TML(AN2) were motile and showed both MSHA and MRHA activity. When grown on BHI agar, all three strains had MRHA activity and were non-motile (Table 3), but differed in that strain TML failed to produce the MSHA under these conditions. The adhesion indices of all broth-grown cultures were similar and in no instance were these significantly reduced by the addition of $0.1 \%$ (w/v) $\alpha$-methyl-D-mannoside to the reaction mixtures (Table 3). TML organisms grown on BHI agar did not attach to HeLa cells (Table 3) because the bacteria were non-motile (Jones et al., 1981). Agar-grown organisms of strains TML(AU6) and TML(AN2), however, did 
Table 3. Haemagglutinating and adhesive properties of MSHA-positive constitutive mutants

\begin{tabular}{|c|c|c|c|c|c|c|c|}
\hline \multirow[b]{2}{*}{ Strain } & \multirow[b]{2}{*}{ Remarks } & \multirow[b]{2}{*}{$\begin{array}{l}\text { Motility } \\
\text { (\%) }\end{array}$} & \multirow[b]{2}{*}{$\begin{array}{l}\text { Relative } \\
\text { MSHA } \\
\text { activity }\end{array}$} & \multirow[b]{2}{*}{$\begin{array}{c}\text { MRHA } \\
\text { titre }\end{array}$} & \multicolumn{2}{|c|}{$\begin{array}{l}\text { Adhesion index for HeLa } \\
\text { cells }( \pm \text { s.D. })\end{array}$} & \multirow[b]{2}{*}{$\begin{array}{l}\text { Invasion } \\
\text { index* }\end{array}$} \\
\hline & & & & & $\begin{array}{l}a-M M \\
\text { absent }\end{array}$ & $\begin{array}{c}\alpha-\mathrm{MM} \\
\text { present }\end{array}$ & \\
\hline \multicolumn{8}{|c|}{ Growth in broth } \\
\hline TML & Wild-type & 60 & $1 \cdot 0$ & 16 & $14 \cdot 1 \pm 2 \cdot 9$ & $15 \cdot 3 \pm 3 \cdot 1$ & $0.69^{a}$ \\
\hline TML(AU6) & $\begin{array}{l}\text { Constitutive MSHA- } \\
\text { positive mutant }\end{array}$ & 70 & $1 \cdot 0$ & 8 & $15 \cdot 3 \pm 3 \cdot 0$ & $14 \cdot 6 \pm 3 \cdot 2$ & $0.73^{a}$ \\
\hline TML(AN2) & $\begin{array}{l}\text { Constitutive MSHA- } \\
\text { positive mutant }\end{array}$ & 70 & $1 \cdot 0$ & 4 & $12.7 \pm 1.6$ & $12 \cdot 7 \pm 2 \cdot 0$ & $0.78^{a}$ \\
\hline \multicolumn{8}{|c|}{ Growth on agar } \\
\hline TML & Wild-type & $<1$ & $\ll 0.01$ & 8 & $1.8 \pm 1.7$ & $1 \cdot 1 \pm 1 \cdot 3$ & $0.05^{b}$ \\
\hline TML(AU6) & $\begin{array}{l}\text { Constitutive MSHA- } \\
\text { positive mutant }\end{array}$ & $<1$ & 1.0 & 4 & $5.6 \pm 0.8$ & $0.6 \pm 1.3$ & $0 \cdot 10^{b}$ \\
\hline TML(AN2) & $\begin{array}{l}\text { Constitutive MSHA- } \\
\text { positive mutant }\end{array}$ & $<1$ & 0.9 & 4 & $4 \cdot 8 \pm 1 \cdot 3$ & $1.1 \pm 0.9$ & $0.14^{b}$ \\
\hline
\end{tabular}

- Proportion of attached bacteria internalized (Jones et al., 1981): $a$, significant proportion internalized $(P<0.001) ; b$, proportion internalized insignificant $(P>0.05)$.

Table 4. Haemagglutinating and adhesive properties of MSHA-negative mutants

\begin{tabular}{|c|c|c|c|c|c|}
\hline \multirow[b]{2}{*}{ Strain } & \multirow[b]{2}{*}{ Remarks } & \multirow{2}{*}{$\begin{array}{l}\text { Relative } \\
\text { MSHA } \\
\text { activity }\end{array}$} & \multirow[b]{2}{*}{$\begin{array}{c}\text { MRHA } \\
\text { titre }\end{array}$} & \multicolumn{2}{|c|}{$\begin{array}{l}\text { Adhesion index for HeLa } \\
\text { cells }( \pm \text { s.D. })\end{array}$} \\
\hline & & & & $\begin{array}{l}\alpha \text {-MM } \\
\text { absent }\end{array}$ & $\begin{array}{c}\text { a-MM } \\
\text { present }\end{array}$ \\
\hline TML & MSHA-positive wild-type & $1 \cdot 0$ & 8 & $10 \cdot 4 \pm 3 \cdot 2$ & $11 \cdot 9 \pm 3.0$ \\
\hline TML(Y42) & MSHA-negative mutant & 0.0 & 4 & $10.4 \pm 2.6$ & $10 \cdot 4 \pm 2 \cdot 1$ \\
\hline TML(N12) & MSHA-negative mutant & 0.0 & 4 & $9.9 \pm 2.6$ & $9 \cdot 2 \pm 2.0$ \\
\hline TML(N15) & MSHA-positive revertant & 0.9 & 4 & $6 \cdot 6 \pm 2.9$ & $8 \cdot 5 \pm 2 \cdot 4$ \\
\hline
\end{tabular}

Table 5. Haemagglutinating and adhesive properties of MSHA-positive transductants

\begin{tabular}{|c|c|c|c|c|c|}
\hline \multirow[b]{2}{*}{ Strain } & \multirow[b]{2}{*}{ Remarks } & \multirow{2}{*}{$\begin{array}{l}\text { Relative } \\
\text { MSHA } \\
\text { activity }\end{array}$} & \multirow[b]{2}{*}{$\begin{array}{c}\text { MRHA } \\
\text { titre }\end{array}$} & \multicolumn{2}{|c|}{$\begin{array}{c}\text { Adhesion index for HeLa } \\
\text { cells }( \pm \text { S.D. })\end{array}$} \\
\hline & & & & $\begin{array}{l}a-\mathrm{MM} \\
\text { absent }\end{array}$ & $\begin{array}{c}\alpha-\mathrm{MM} \\
\text { present }\end{array}$ \\
\hline $\mathbf{S 8 5 0}$ & Recipient & 0.0 & 8 & $15.8 \pm 3.4$ & $15 \cdot 9 \pm 3 \cdot 1$ \\
\hline PR & Donor & $1 \cdot 0$ & 4 & $10.8 \pm 3.0$ & $13 \cdot 7 \pm 3 \cdot 2$ \\
\hline S850(PR22T) & MSHA-positive transductant & $1 \cdot 0$ & 8 & $8.9 \pm 2.9$ & $16 \cdot 2 \pm 3 \cdot 2$ \\
\hline S850(PR 16T) & MSHA-positive transductant & 1.0 & 4 & $10.2 \pm 1.9$ & $15.6 \pm 3.6$ \\
\hline
\end{tabular}

attach to HeLa cells to a reduced extent but attachment was inhibited by $0.1 \%(\mathrm{w} / \mathrm{v})$ a-methyl-D-mannoside (Table 3). No agar-grown bacteria were internalized by HeLa cells even in the absence of $a$-methyl-D-mannoside; broth-grown bacteria invaded to the extent expected (Table 3).

MSHA-negative mutants. Non-fimbriate mutant strains TML(Y42) and TML(N12) did not elaborate the MSHA when grown in liquid medium but did show MRHA activity and normal motility. Such mutants adhered to HeLa cells and adhesion was not reduced in the presence of $\alpha$-methyl-D-mannoside (Table 4). Strain TML(N15), an MSHA-positive revertant clone of strain TML(N12), was no more adhesive than strain TML(N12) (Table 4). Organisms of all four strains were internalized by the HeLa cells to similar extents (results not shown). 
Table 6. Haemagglutinating and adhesive properties of cultures grown at $18^{\circ} \mathrm{C}$ and $37{ }^{\circ} \mathrm{C}$

\begin{tabular}{|c|c|c|c|}
\hline Strain & $\begin{array}{c}\text { Relative MSHA } \\
\text { activity }\end{array}$ & MRHA titre & $\begin{array}{r}\text { Adhesion index for } \\
\text { cells }( \pm \text { S.D. })\end{array}$ \\
\hline \multicolumn{4}{|c|}{ Growth at $37^{\circ} \mathrm{C}$} \\
\hline S850 & 0.0 & 16 & $16 \cdot 1 \pm 3 \cdot 6$ \\
\hline S2204 & 0.0 & 8 & $5.8 \pm 1.6$ \\
\hline TML & 1.0 & 16 & $9.7 \pm 3.3$ \\
\hline W118 & 1.0 & 16 & $14 \cdot 2 \pm 3 \cdot 3$ \\
\hline NY & 1.0 & 16 & $18 \cdot 8 \pm 4.4$ \\
\hline PR & $1 \cdot 0$ & 8 & $11.5 \pm 4.0$ \\
\hline \multicolumn{4}{|c|}{ Growth at $18^{\circ} \mathrm{C}$} \\
\hline S850 & 0.0 & $<2$ & $1 \cdot 1 \pm 1 \cdot 7$ \\
\hline S2204 & 0.0 & 16 & $6.4 \pm 2.0$ \\
\hline TML & 0.15 & 16 & $7 \cdot 7 \pm 3 \cdot 4$ \\
\hline W118 & 0.65 & $<2$ & $2 \cdot 6 \pm 2 \cdot 0$ \\
\hline NY & 0.50 & $<2$ & $1.5 \pm 1.5$ \\
\hline PR & $0 \cdot 30$ & $<2$ & $0.8 \pm 1.5$ \\
\hline
\end{tabular}

Table 7. Haemagglutinating and adhesive properties of MRHA-negative mutants

\begin{tabular}{|c|c|c|c|c|c|c|}
\hline \multirow[b]{2}{*}{ Strain } & \multirow[b]{2}{*}{ Remarks } & \multirow{2}{*}{$\begin{array}{l}\text { Relative } \\
\text { MSHA } \\
\text { activity }\end{array}$} & \multirow[b]{2}{*}{$\begin{array}{c}\text { MRHA } \\
\text { titre }\end{array}$} & \multicolumn{2}{|c|}{$\begin{array}{l}\text { Adhesion index for HeLa } \\
\text { cells }( \pm \text { S.D. })\end{array}$} & \multirow[b]{2}{*}{$\begin{array}{c}\text { Invasion } \\
\text { index* }\end{array}$} \\
\hline & & & & $\begin{array}{l}\alpha-M M \\
\text { absent }\end{array}$ & $\begin{array}{c}\alpha-\mathrm{MM} \\
\text { present }\end{array}$ & \\
\hline TML & MRHA-positive wild-type & 1.0 & 16 & $9 \cdot 8 \pm 2 \cdot 8$ & $10 \cdot 6 \pm 2 \cdot 6$ & $0.74^{a}$ \\
\hline TML(16) & MRHA-negative mutant & 0.8 & $<2$ & $1.9 \pm 2.4$ & $0.6 \pm 1 \cdot 1$ & $0.06^{b}$ \\
\hline TML(54) & MRHA-negative mutant & $1 \cdot 0$ & $<2$ & $1.4 \pm 1.6$ & $1 \cdot 2 \pm 1 \cdot 2$ & $0 \cdot 10^{b}$ \\
\hline TML(72) & MRHA-negative mutant & $1 \cdot 0$ & $<2$ & $1.0 \pm 1.8$ & $0.9 \pm 1.3$ & $0.21^{b}$ \\
\hline TML(161A) & MRHA-positive revertant & 1.0 & 2 & $7 \cdot 5 \pm 2 \cdot 6$ & $9.6 \pm 2.8$ & $0.69^{a}$ \\
\hline
\end{tabular}

* Proportion of attached bacteria internalized (Jones et al., 1981): a, significant proportion internalized $(P<0.001) ; b$, proportion internalized insignificant $(P>0.05)$.

MSHA-positive transductants. The MSHA-positive transductants of strain S850 retained their ability to attach to HeLa cells (Table 5), but only when $\alpha$-methyl-D-mannoside was present did the organisms attach to an extent similar to that of the recipient strain S850. In the absence of this carbohydrate, the transductants were only as adhesive as the donor strain PR (Table 5). Other MSHA-positive transductants of strain S850, derived with phage lysates of strain 18, behaved in a similar manner (results not shown). Similar proportions of attached organisms of all strains became intracellular within $3 \mathrm{~h}$ (results not shown).

MRHA-negative phenotypes. Bacteria of all six wild-type strains of $S$. typhimurium adhered to HeLa cells when grown in broth at $37^{\circ} \mathrm{C}$, whereas only strains TML and S2204 did so after growth at $18^{\circ} \mathrm{C}$ (Table 6). Strains S2204 and TML were the only strains to show MRHA activity at the lower incubation temperature. Although MSHA production was also less at $18^{\circ} \mathrm{C}$ than at $37^{\circ} \mathrm{C}$, the greatest reduction in MSHA activity was exhibited by cultures of the adhesive strain TML (Table 6).

MRHA-negative mutants. The three independently derived MRHA-negative mutants of strain TML [strains TML(16), TML(54) and TML(72)] failed to adhere to HeLa cells although normal motility and MSHA production was apparent (Table 7). After incubation with $\mathrm{HeLa}$ cell monolayers for $3 \mathrm{~h}$ in the standard invasion test, the total number of bacteria associated with the HeLa cells increased by a factor of about two, but little or no invasion of the HeLa cells occurred (Table 7).

The MHRA titres of cultures of the MRHA-positive revertant strain TML(161A) were seldom greater than 2 (Table 7). Nevertheless, the reappearance of this level of MRHA 
activity in a culture coincided with the renewed ability of the bacteria to adhere to HeLa cells (Table 7). Conversely, the spontaneous loss of detectable MRHA activity (i.e. MRHA titre $<2$ ) from cultures of the more unstable revertants occurred concomitantly with the loss of the ability to adhere to HeLa cells.

\section{DISCUSSION}

The ability of non-fimbriate strains of the FIRN biogroup to attach to HeLa cells demonstrated clearly that type 1 fimbriae could not be responsible for the attachment of all $S$. typhimurium strains (summarized in Table 8, lines 1 and 2). Indeed, the mannose-resistant nature of the adhesive properties of bacteria of both fimbriate and non-fimbriate strains implicated an adhesive mechanism other than that provided by type 1 fimbriae which possess MSHA activity. Candidates for such a role are the MRHA activities which were detected in cultures of all six strains. These MRHA activities were superficially similar in that their detection was restricted to the microhaemagglutination test; they displayed similar agglutinating activities with erythrocytes of different species; and all were most active in the cold and none were inhibited by D-mannose. They appeared to differ only in respect to production at $18{ }^{\circ} \mathrm{C}$, an observation that may indicate the existence of different types of MRHA activity. However, the two strains that produced MRHA at $18^{\circ} \mathrm{C}$ are probably phylogenetically distinct, as is the one FIRN strain that failed to produce MRHA (Duguid $e t$ al., 1975; Old \& Duguid, 1979). It is more probable that the inhibition of MRHA production at $18{ }^{\circ} \mathrm{C}$ was strain dependent and perhaps due to difficulties in transportation of the MRHA to the microbial surface at this temperature. Such possibilities are indicated by studies on the temperature-dependent production of the K99 haemagglutinin (de Graff et al., 1980).

The presence of MRHA activity was correlated with the ability to attach to HeLa cells in tests with broth cultures grown at $18^{\circ} \mathrm{C}$ and $37^{\circ} \mathrm{C}$ (Table 8, lines 6 and 7,1 and 2), and in the analysis of MRHA-negative/MSHA-positive mutants and their MRHA-positive/MSHApositive revertants (Table 8, line 5). The MRHA titre and the adhesion index, however, did not correlate. The haemagglutination test measured the MRHA content of the culture, whereas the adhesion test detected those cells capable of adhering to HeLa cells. If attachment to HeLa cells requires a certain amount of adhesin per bacterium, then all bacteria with adhesin in excess of this level would attach regardless of the haemagglutinin content of the whole culture.

The MSHA activity of fimbriate strains participated little, if at all, in the attachment of salmonellae to HeLa cells. Firstly, MRHA-negative/MSHA-positive mutants failed to adhere to any significant degree (Table 8, line 5). Secondly, MRHA-positive/MSHA-negative bacteria were as adhesive as the parent bacteria (Table 8 , line 3). Thirdly, the fimbriate strain which produced the least amount of MSHA when grown at $18^{\circ} \mathrm{C}$ was the only fimbriate strain to attach after growth at this temperature. Only in suspensions of agar-grown, non-motile bacteria that were constitutive for fimbriae production was mannose-sensitive attachment apparent (Table 8, line 9). It seems likely, however, that the mannose-sensitive and mannose-resistant forms of attachment require different conditions for their expression. For instance, motility is not essential for the attachment of non-motile Shigella flexneri to animal cells via type 1 fimbriae (Duguid \& Gillies, 1957), whereas motility is necessary for the usual form of salmonella attachment to HeLa cells (Jones et al., 1981). The present studies show this motility-dependent attachment to be mannose-resistant. Conversely, previous studies showed that agitation of the test mixture enhances the adhesive activity of type 1 fimbriae in Escherichia coli (Jones \& Rutter, 1974), but agitation prevents the adhesion of salmonellae to HeLa cells (Jones et al., 1981). Consequently, the contribution of type 1 fimbriae to attachment may be expected to be low under the static conditions of the HeLa cell test. Mannose-sensitive attachment, therefore, may be detected only occasionally when the mannose-resistant adhesin is absent or inactive or MSHA activity is enhanced. 
Table 8. Summary of results

Results designated + indicate the property was present (motility $>60 \%$ ), - indicates no measurable activity existed (motility $<1 \%$ ), and $+/$ - indicates the property was strain dependent.

\begin{tabular}{|c|c|c|c|c|c|c|c|}
\hline \multirow[b]{2}{*}{ Phenotype } & \multirow[b]{2}{*}{$\begin{array}{l}\text { Representative } \\
\text { strain(s) }\end{array}$} & \multirow[b]{2}{*}{ Motility } & \multirow[b]{2}{*}{$\begin{array}{l}\text { MSHA } \\
\text { activity }\end{array}$} & \multirow[b]{2}{*}{$\begin{array}{l}\text { MRHA } \\
\text { activity }\end{array}$} & \multicolumn{2}{|c|}{$\begin{array}{c}\begin{array}{c}\text { Adhesion to HeLa } \\
\text { cells }\end{array} \\
\text { A }\end{array}$} & \multirow[b]{2}{*}{$\begin{array}{c}\text { Invasion } \\
\text { of HeLa cells }\end{array}$} \\
\hline & & & & & $\begin{array}{c}\text { a-MM* } \\
\text { absent }\end{array}$ & $\begin{array}{l}\alpha-\mathbf{M M}^{*} \\
\text { present }\end{array}$ & \\
\hline \multicolumn{8}{|c|}{ Growth in broth at $37^{\circ} \mathrm{C}$} \\
\hline 1. FIRN & $\mathbf{S 8 5 0}$ & + & - & + & + & + & + \\
\hline 2. Non-FIRN & TML & + & + & + & + & + & + \\
\hline 3. MSHA-negative & TML(Y42) & + & - & + & + & + & + \\
\hline 4. MSHA-positive & S850(PR22T) & + & + & + & $+\dagger$ & + & + \\
\hline 5. MRHA-negative & TML(16) & + & + & - & - & - & - \\
\hline \multicolumn{8}{|c|}{ Growth in broth at $18^{\circ} \mathrm{C}$} \\
\hline 6. MRHA-negative & PR/S850 & + & $+1-$ & - & - & - & - \\
\hline 7. MRHA-positive & TML/S2204 & + & $+1-$ & + & + & + & + \\
\hline \multicolumn{8}{|c|}{ Growth on agar at $37^{\circ} \mathrm{C}$} \\
\hline 8. MSHA-negative & TML & - & - & + & - & - & - \\
\hline 9. MSHA-positive & TML(AU6) & - & + & + & + & - & - \\
\hline
\end{tabular}

The attachment of type 1 fimbriae is indicated by the observation that adhesion of fimbriate transductants was enhanced in the presence of D-mannose. This suggested that type 1 fimbriae bound to HeLa cells, but in so doing reduced attachment mediated by MRHA activity (Table 8 , line 4). Inhibition by D-mannose of the binding of type 1 fimbriae could allow MRHA determinants to have greater access to the HeLa cell surface and hence cause increased bacterial attachment. Where MSHA type 1 fimbrial attachment is established it is likely that the distance between the animal cell surface and the bacterial cell is too great to allow MRHA-mediated attachment. This interpretation is consistent with a previous conclusion (Jones et al., 1981) that the main $S$. typhimurium adhesin (i.e. MRHA) effectively promoted binding of bacteria to HeLa cells only when a small distance (about $15 \mathrm{~nm}$ ) separated the two surfaces. The same explanation may be offered for the apparent inactivity of the MRHA of non-motile bacteria attached to HeLa cells in a mannose-sensitive manner (Table 8, line 9).

The opinion (reviewed by Kihlström, 1980) that rough cell-wall characteristics play an important role in the interaction of $S$. typhimurium with HeLa cells and the one presented here, that the MRHA of smooth bacteria is of importance, are reconcilable. Real differences may exist in some of the ways that rough and smooth salmonellae enter the initial phase of reversible attachment that precedes irreversible attachment or adhesion (Jones et al., 1981). Initial contact by mutants with rough cell-walls, conceivably, could be caused by their adsorption to animal cells by virtue of the increased hydrophobic characteristics of their surface (Stendahl et al., 1973; Van Oss, 1978). Smooth bacterial cells, in contrast, are known to achieve this initial contact through motility (Jones et al., 1981). Once initial contact has been accomplished, however, the adhesion of both rough and smooth cells of $S$. typhimurium to HeLa cells may be similar and involve the MRHA.

The internalization of $S$. typhimurium by HeLa cells correlated only with mannoseresistant attachment of the bacteria to the HeLa cells. The form of attachment, therefore, appeared to play an important role in the internalization process. On the one hand, attachment may need to be specific in that only binding of the mannose-resistant adhesin to its HeLa cell receptor will affect internalization. On the other hand, internalization may depend on a minimal number of bonds being formed between the bacterium and HeLa cell 
and/or the formation of bonds of a minimal strength (Griffin et al., 1975; Capo et al., 1978). In the latter case, it must be assumed that in the HeLa cell system these conditions are fulfilled only in MRHA-mediated adhesion. In other test systems in which the animal cell is a professional phagocyte, the binding of type 1 fimbriae is sufficient to enhance internalization (Silverblatt et al., 1979). This apparent contradiction, therefore, may be the result of differences in specific ligand binding sites on the animal cells or due to the extent of type 1 fimbrial bonding of the bacteria to animal cells. There are few type 1 fimbrial binding sites, for example, on uroepithelial cells (Ørskov et al., 1980) and some species of erythrocyte (Duguid \& Old, 1980).

Salmonella typhimurium, therefore, produces two adhesins, each of which presumably has some specific and unique function. The precise nature of the putative mannose-resistant adhesin and how it may interact with animal cell receptors to facilitate bacterial entry into the host cell may be of importance to the understanding of these pathogens.

This work was supported by Biomedical Research Support Grant RR 05383 awarded to the University of Michigan by the National Institutes of Health and by Public Health Service Grant AI-13842 from the National Institute of Allergy and Infectious Diseases.

\section{REFERENCES}

BEACHEY, E. H. (editor) (1980). Bacterial Adherence. Receptors and Recognition, Series B, vol. 6. London \& New York: Chapman \& Hall.

BeCKeR, Y. (1978). The chlamydia: molecular biology of procaryotic obligate parasites of eucaryotes. Microbiological Reviews 42, 274-306.

BrowNRIDGE, E. \& WYRICK, P. B. (1979). Interaction of Chlamydia psittaci reticulate bodies with mouse peritoneal macrophages. Infection and Immunity 24, $697-700$.

BYrne, G. I. \& Moulder, J. W. (1978). Parasitespecific phagocytosis of Chlamydia psittaci and Chlamydia trachomatis by $\mathrm{L}$ and HeLa cells. Infection and Immunity 19, 598-606.

Capo, C., Bongrand, P., Benoliel, A. M. \& DEPIEDS, R. (1978). Dependence of phagocytosis on strengths of phagocyte-particle interaction. Immunology 35, 117-182.

Carrol, M. E. W., Jackett, P. S., Aber, V. R. \& LOWRIE, D. B. (1979). Phagolysosome formation, cyclic adenosine $3^{\prime}: 5^{\prime}$-monophosphate and the fate of Salmonella typhimurium within mouse peritoneal macrophages. Journal of General Microbiology 110 , 421-429.

DE GrafF, F. K., WientJes, F. B. \& KLAASEN-BooR, P. (1980). Production of K99 antigen by enterotoxigenic Escherichia coli strains of antigen groups 08 , 09,020 , and 0101 grown at different conditions. Infection and Immunity 27, 216-221.

Duguid, J. P. \& Ğllies, R. R. (1957). Fimbriae and adhesive properties in dysentery bacilli. Journal of Pathology and Bacteriology 74, 397-411.

Duguid, J. P. \& OLD, D. C. (1980). Adhesive properties of Enterobacteriaceae. In Bacterial Adherence. Receptors and Recognition, Series B, vol. 6, pp. 185-217. Edited by E. H. Beachey. London \& New York: Chapman \& Hall.

Duguid, J. P., Anderson, E. S. \& Campbell, I. (1966). Fimbriae and adhesive properties in salmonellae. Journal of Pathology and Bacteriology 92, 107-138.

Duguid, J. P., ANDerson, E. S., Alfredsson, G. A.,
BARKER, R. \& OLD, D. C. (1975). A new biotyping scheme for Salmonella typhimurium and its phylogenetic significance. Journal of Medical Microbiology 8, 149-166.

Freter, R., O'Brien, P. C. M. \& Macsal, M. S. (1979). Effect of chemotaxis on the interaction of cholera vibrios with intestinal mucosa. American Journal of Clinical Nutrition 32, 128-132.

GeMSKI, P. \& Formal, S. B. (1975). Shigellosis: an invasive infection of the gastrointestinal tract. In Microbiology - 1975, pp. 165-169. Edited by D. Schlessinger. Washington, D.C.: American Society for Microbiology.

Giannella, R. A., Washington, O., Gemski, P. \& FormaL, S. B. (1973). Invasion of HeLa cells by Salmonella typhimurium: a model for study of invasiveness of salmonella. Journal of Infectious Diseases 128, 69-75.

Gregory, W. W., BYrne, G. I., GARDNER, M. \& Moulder, J. W. (1979). Cytochalasin B does not inhibit ingestion of Chlamydia psittaci by mouse fibroblasts ( $\mathrm{L}$ cells) and mouse peritoneal macrophages. Infection and Immunity 25, 463-466.

Griffin, F. M., GriffiN, J. A., Leider, J. E. \& Silverstein, S. C. (1975). Studies on the mechanism of phagocytosis. I. Requirements for circumferential attachment of particle-bound ligands to specific receptors on the macrophage plasma membrane. Journal of Experimental Medicine 142, 1263-1282.

Hale, T. L. \& Bonventre, P. F. (1979). Shigella infection of Henle intestinal epithelial cells: role of the bacterium. Infection and Immunity 24, 879-886.

Hale, T. L., Morris, R. E. \& Bonventre, P. F. (1979). Shigella infection of Henle intestinal epithelial cells: role of the host cell. Infection and Immunity 24, 887-894.

hart, P. D., Armstrong, J. A., Brown, C. A. \& DraPER, P. (1972). Ultrastructural study of the behavior of macrophages towards parasitic mycobacteria. Infection and Immunity 5, 803-807.

Hirata, A. A. \& Brandriss, W. H. (1968). Passive 
hemagglutination procedures for protein and polysaccharide antigens using erythrocytes stabilized by aldehydes. Journal of Immunology 100, 641-646.

JoNES, G. W. (1977). The attachment of bacteria to the surfaces of animal cells. In Microbial Interactions. Receptors and Recognition, Series B, vol. 3, pp. 139-176. Edited by J. L. Reissig. London \& New York: Chapman \& Hall.

Jones, G. W. \& Freter, R. (1976). Adhesive properties of Vibrio cholerae: nature of the interaction with isolated rabbit brush-border membranes and human erythrocytes. Infection and Immunity 14, 240-245.

JONES, G. W. \& RUTTER, J. M. (1974). The association of $\mathrm{K} 88$ antigen with haemagglutinin activity in porcine strains of Escherichia coli. Journal of General Microbiology 84, 135-144.

Jones, G. W., Richardson, L. A. \& Uhlman, D. (1981). The invasion of HeLa cells by Salmonella typhimurium: reversible and irreversible bacterial attachment and the role of bacterial motility. Journal of General Microbiology 127, 351-360.

JONES, T. C. \& HiRSCH, J. G. (1972). The interaction between Toxoplasma gondii and mammalian cells. II. The absence of lysosomal fusion with phagocytic vacuoles containing living parasites. Journal of Experimental Medicine 136, 1173-1194.

KıHLSTRÖM, E. (1980). Interaction between salmonella bacteria and mammalian non-professional phagocytes. American Journal of Clinical Nutrition 33, 2491-2501.

Kinlström, E. \& Edebo, L. (1976). Association of viable and inactivated Salmonella typhimurium 395MS and MR 10 with HeLa cells. Infection and Immunity 14, 851-857.

Kinlström, E. \& LATKovic, S. (1978). Ultrastructural studies on the interaction between Salmonella typhimurium 395MS and HeLa cells. Infection and Immunity 22, 804-809.

LeBrec, E. H., Schneider, H., Magnani, T. J. \& FORMAL, S. B. (1964). Epithelial cell penetration as an essential step in the pathogenesis of bacillary dysentery. Journal of Bacteriology 88, 1503-1518.

NORRBY, R. \& LYCKE, E. (1967). Factors enhancing the host-cell penetration of Toxoplasma gondii. Journal of Bacteriology 93, 53-58.

Old, D. C. \& Duguid, J. P. (1971). Selection of fimbriate transductants of Salmonella typhimurium dependent on motility. Journal of Bacteriology 107, 655-658.
Old, D. C. \& Duguid, J. P. (1979). Transduction of fimbriation demonstrating common ancestry in FIRN strains of Salmonella typhimurium. Journal of General Microbiology 112, 251-259.

ØRSKOV, I., ØRSKOV, F. \& BIRCH-ANDERSEN, A. (1980). Comparison of Escherichia coli fimbrial antigen F7 with type 1 fimbriae. Infection and Immunity 27, 657-666.

Otтow, J. C. G. (1975). Ecology, physiology and genetics of fimbriae and pili. Annual Review of Microbiology 29, 79-108.

Silverblatt, F. J., Dreyer, J. S. \& Schauer, S. (1979). Effect of pili on susceptibility of Escherichia coli to phagocytosis. Infection and Immunity 24, 218-223.

Silverstein, S. C., Steinman, R. M. \& Cohn, Z. A. (1977). Endocytosis. Annual Review of Biochemistry 46, 669-722.

SMyth, C. J., Jonsson, P., Olsson, E., Sonderlind, O., Rosengren, J., HJerten, S. \& Wadstrom, T (1978). Differences in hydrophobic surface characteristics of porcine enteropathogenic Escherichia coli with and without $\mathrm{K} 88$ antigen as revealed by hydrophobic interaction chromatography. Infection and Immunity 22, 462-472.

Stendahl, O., Tagesson, C. \& Edebo, M. (1973). Partition of Salmonella typhimurium in a twopolymer aqueous system in relation to liability to phagocytosis. Infection and Immunity 8, 36-41.

Stossel, T. P. (1975). Phagocytosis: recognition and ingestion. Seminars in Hematology 12, 83-116.

TAKEUCHI, A. (1967). Electron microscope studies of experimental salmonella infection. I. Penetration into the intestinal epithelium by Salmonella typhimurium. American Journal of Pathology 50, 109136.

Takeuchi, A., Sprinz, H., LeBrec, E. H. \& Formal, S. B. (1965). Experimental bacillary dysentery: an electron microscopic study of the response of the intestinal mucosa to bacterial invasion. American Journal of Pathology 47, 1011-1044.

Van Oss, C. J. (1978). Phagocytosis as a surface phenomenon. Annual Review of Microbiology 32, 19-39.

Wilkinson, R. G., Gemski, P. \& Stocker, B. A. D. (1972). Non-smooth mutants of Salmonella typhimurium: differentiation by phage sensitivity and genetic mapping. Journal of General Microbiology 70, 527-554. 